\title{
2003 Mw6.8 Chengkung earthquake and its related seismogenic structures
}

\author{
Hao Kuochen ${ }^{\mathrm{a}, *}$, Yih-Min Wu ${ }^{\mathrm{b}}$, Yue-Gau Chen ${ }^{\mathrm{b}}$, Rong-Yuh Chen ${ }^{\mathrm{a}}$ \\ ${ }^{a}$ Seismological Observation Center of the Central Weather Bureau, Taipei, Taiwan, ROC \\ b Department of Geosciences, National Taiwan University, Taipei, Taiwan, ROC
}

Received 13 July 2004; received in revised form 14 July 2005; accepted 27 July 2006

\begin{abstract}
The $\mathrm{Mw}=6.8$ Chengkung earthquake on December 10, 2003 in eastern Taiwan was associated with abundant aftershocks. To explore the seismogenic mechanism and its causative fault system, we relocated the aftershocks, determined the focal mechanisms from P-wave polarities and used the Finite Dimension Source Model method to identify the fault plane. Based on our results, the earthquake can be divided into three seismic clusters: one is located in the east of the southern Longitudinal Valley, one on the Chihshang fault, and the other on the western side of the Luyeh fault to the south. Both the seismic distribution and Finite Dimension Source Model method show that east-dipping fault planes with thrust mechanisms coincide with previous studies based on background seismicity. The third seismic cluster suggests thrust mechanism along west-dipping fault plane that was not recognized by background seismicity. This seismic cluster occurred along the Central Range Fault previously proposed as active by geomorphic and geologic evidence.
\end{abstract}

(C) 2007 Elsevier Ltd. All rights reserved.

Keywords: Earthquake; Eastern Taiwan

\section{Introduction}

The Chengkung earthquake $(\mathrm{Mw}=6.8)$ occurred on December 10, 2003 at a focal depth of $10.0 \mathrm{~km}$, as reported by the Central Weather Bureau (CWB). The main shock occurred at $23.10^{\circ} \mathrm{N}$ and $121.34^{\circ} \mathrm{E}$ along the eastern coast of Taiwan near the town of Chengkung (Fig. 1a). The region also experienced damage to structures during the November 24, 1951 Taitung earthquake $(\mathrm{Mw}=7.0)$. The Taitung earthquake caused 17 casualties and damages to 1016 houses (Hsu, 2003). In contrast, the 2003 Chengkung earthquake resulted in slight damage of buildings and constructions of nearby harbor facilities, leading to limited property loss. After the main shock, thousands of aftershocks occurred, including $11 M_{\mathrm{L}} \geqslant 5.0$ events that took

\footnotetext{
* Corresponding author. Address: 321 Main Street, Apt\#2, Binghamton, NY 13905, United States. Tel.: +1 2672434651.

E-mail address: kuochen.hao@gmail.com (H. Kuochen).
}

place, between December 10 and December 31 of 2003 (Table 1).

The Longitudinal Valley (LV) of eastern Taiwan marks the suture zone of an arc-continent collision, producing an active orogeny that began to develop in the late Miocene (Ho, 1986; Teng, 1992). The current stress field determined by GPS shows that the major principle stress is oriented $308^{\circ}(\mathrm{Yu}$ et al., 1997; $\mathrm{Hu}$ et al., 1997), nearly orthogonal to tectonostratigraphic belts such as the Coastal Range and Longitudinal Valley in eastern Taiwan. Two active fault systems with opposite vergence have been mapped (Biq, 1965) along mountain fronts of valley side of the Coastal as well as Central Range. Accordingly, they are named as the Coastal and Central Range faults. The southern segment of the Coastal Range fault (e.g., Chihshang fault) is the seismogenic fault of 1951 Taitung earthquake (Hsu, 1962). Based on the patterns of surface rupture, this fault is segmented and has nearly equal components of vertical and horizontal slip. In order to understand the mechanism and geometry 


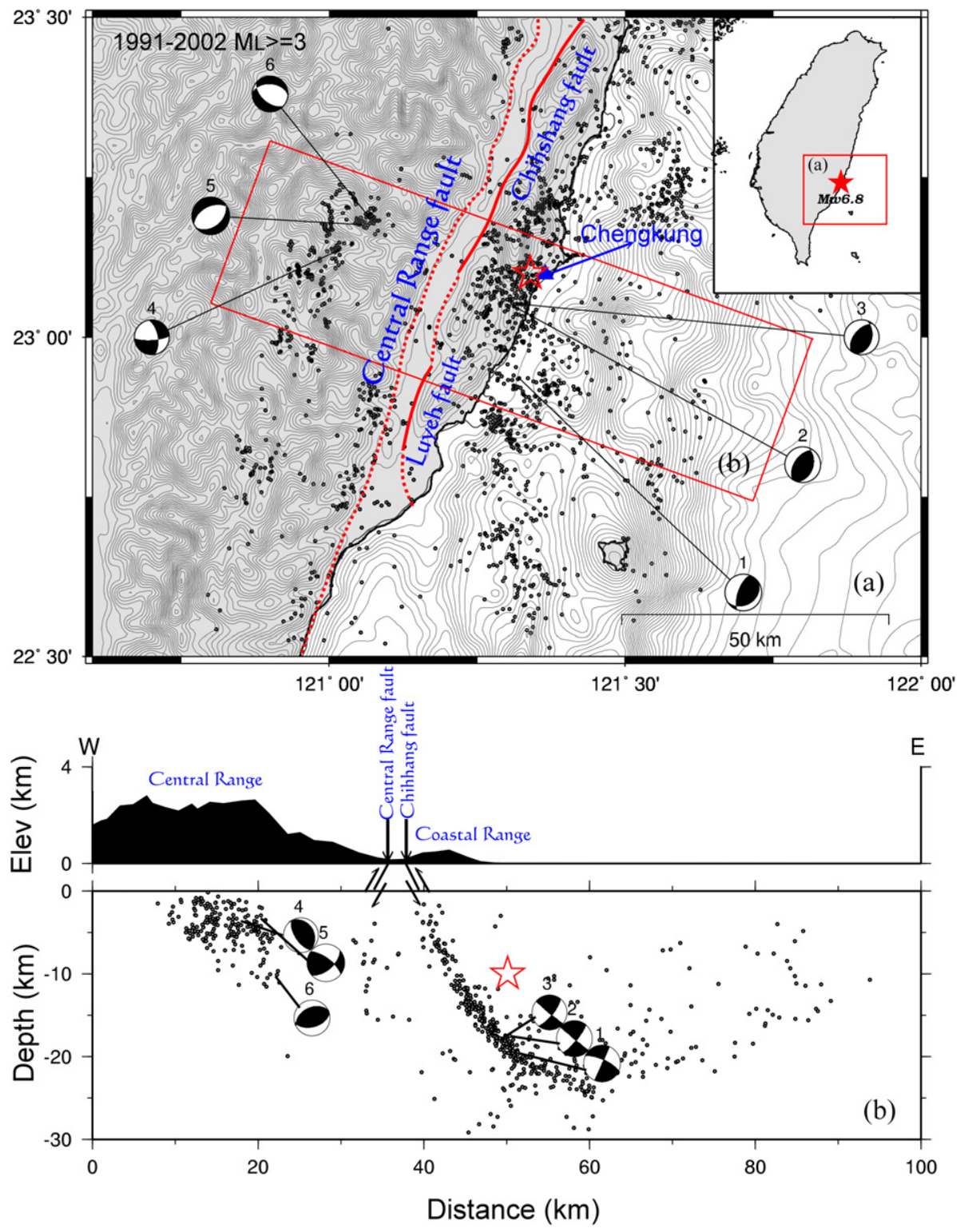

Fig. 1. (a) The distribution of relocated epicenters of the background seismicity from 1991 to 2002 in eastern Taiwan and the focal mechanisms of $M_{L} \geqslant 5.0$ (Kuochen et al., 2004). The red star shows the location of 2003 Chengkung main shock (CWB). The solid-triangles show the location of Chengkung. (b) Cross-section of projected hypocenters and the focal mechanisms. (For interpretation of the references to color in this figure legend, the reader is referred to the web version of this paper.)

Table 1

The parameters of 2003 Chengkung main shock and aftershocks: the earthquakes $M_{\mathrm{L}} \geqslant 5.0$ of the CWB earthquake reports from $12 / 10$ to $12 / 31$ (No. 1 is the main shock and No. 2-12 are aftershocks)

\begin{tabular}{|c|c|c|c|c|c|}
\hline No & Time (Universal Time) & Latitude $\left({ }^{\circ} \mathrm{N}\right)$ & Longitude $\left({ }^{\circ} \mathrm{E}\right)$ & Depth $(\mathrm{km})$ & $M_{\mathrm{L}}$ \\
\hline 1 & 2003/12/10 04:38:15 & 23.10 & 121.34 & 10.0 & 6.6 \\
\hline 2 & 2003/12/10 04:42:55 & 23.06 & 121.30 & 17.5 & 5.1 \\
\hline 3 & 2003/12/10 04:50:44 & 23.11 & 121.29 & 15.8 & 5.0 \\
\hline 5 & 2003/12/10 06:41:27 & 22.90 & 121.32 & 19.1 & 5.0 \\
\hline 6 & 2003/12/10 08:10:32 & 22.92 & 121.28 & 22.1 & 5.0 \\
\hline 7 & $2003 / 12 / 1008: 46: 44$ & 22.93 & 121.38 & 13.6 & 5.5 \\
\hline 10 & $2003 / 12 / 1322: 53: 29$ & 23.06 & 121.18 & 10.0 & 5.0 \\
\hline 11 & $2003 / 12 / 16 \quad 13: 56: 59$ & 23.12 & 121.33 & 13.1 & 5.3 \\
\hline 12 & $2003 / 12 / 17 \quad 16: 27: 24$ & 22.61 & 121.40 & 13.6 & 5.8 \\
\hline
\end{tabular}




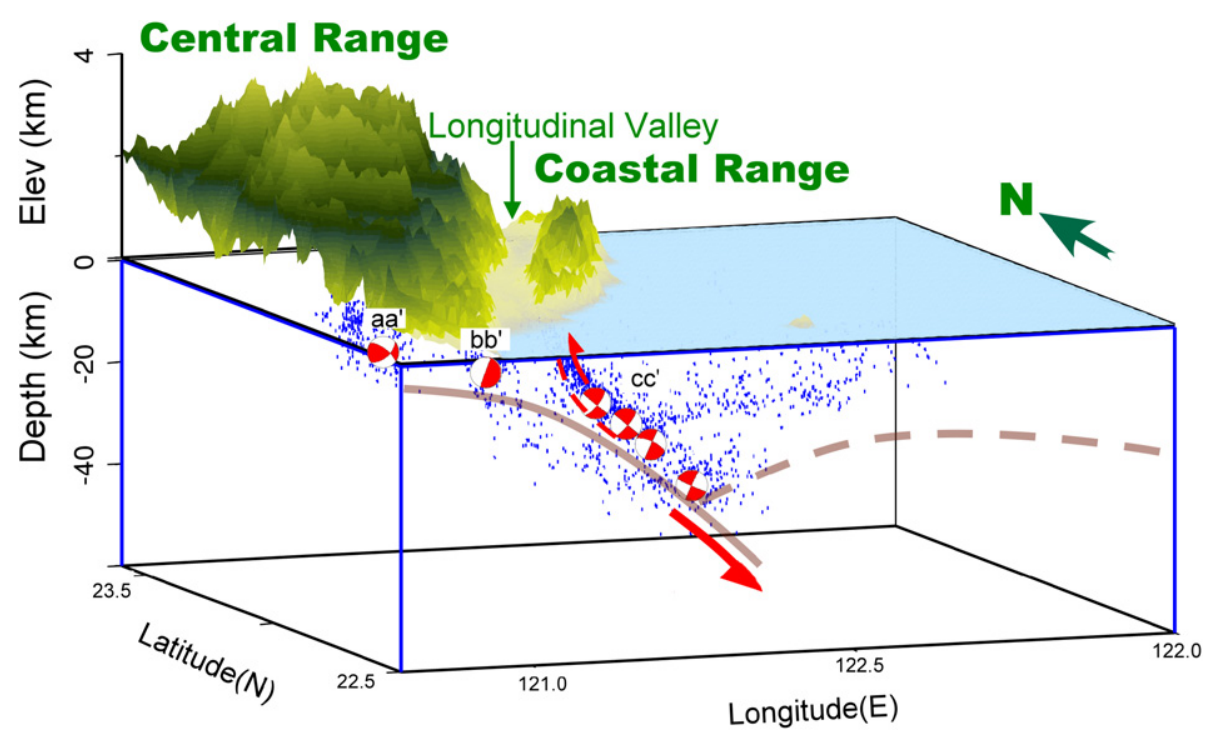

Fig. 2. The model of the seismic patterns in southeastern Taiwan. $\mathrm{aa}^{\prime}, \mathrm{bb}^{\prime}, \mathrm{cc}^{\prime}$ show the three seismic zones in eastern Taiwan: aa', the eastern side of the Central Range (normal type fault plane solutions); $\mathrm{bb}^{\prime}$, the western side of Longitudinal Valley (strike-slip type fault plane solutions); $\mathrm{cc}^{\prime}$, the right-hand side of Longitudinal Valley (thrust type fault plane solutions) (Kuochen et al., 2004). The lowest depth of the distribution of the seismicity is similar to the results of Carena et al. (2002).

of active structures in eastern Taiwan, we previously relocated earthquakes from the CWB catalog and determined the fault plane solutions of the $M_{\mathrm{L}} \geqslant 5.0$ events (Kuochen et al., 2004; Figs. 1 and 2). Faults in southeastern Taiwan include the east-dipping LV suture zone illuminated by seismicity contained along the edge of the Luzon arc. Focal mechanism solutions of these events were thrust-type. Along the Longitudinal Valley, there also exists a shallow seismic zone marked by a strike-slip focal mechanism event. Geological and geomorphic studies also indicate that the $\mathrm{N}-\mathrm{S}$ trending left-lateral shearing and transpression structures dominate along the eastern boarder of the southern Central Range (Lu et al., 2002). In the eastern Central Range, shallow events with normal type of focal mechanisms record local extension (Fig. 2).

In the Chengkung region, seismicity defines a zone of east-dipping listric faults that extend downward to a depth of $20 \mathrm{~km}$ (Fig. 1b). We name this trend of seismicity the Chengkung seismic zone. The surface extension of the seismic zone stretches nearly to the western margin of the Coastal Range, which is the location of the Coastal Range fault. Focal mechanisms are also predominated by thrust events, thus we suggest that this zone may reflect the 3D image of subsurface of the Coastal Range fault.

The 2003 Chengkung earthquake again provided an opportunity to refine the geometry and style of faulting using the double difference method (hypoDD, Waldhauser and Ellsworth, 2000) by relocating hypocenters of the main shock and aftershocks of 2003 Chengkung earthquake. In addition, we determined focal mechanisms from the first motion polarities, and identified the fault plane by applying finite dimension source model method (FDSM, Legrand and Delouis, 1999).

\section{Data analysis}

\subsection{Seismic data and relocation method}

The Central Weather Bureau seismic network (CWBSN) consists of a central recording system that is equipped with 73 telemetered stations and three-component S13 seismometers. Seismic signals digitized at 12 bits and 100 samples per second from each station are transmitted via dedicated telephone line to the center station in Taipei. After the occurrence of the Chengkung earthquake, a total of 372 events from $12 / 10 / 03$ to $12 / 31 / 03$ were selected for earthquakes relocation. The selection was based on the following criteria: (1) earthquakes were located in the region bounded by $22.5-23.5^{\circ} \mathrm{N}$ Latitude and $121-122^{\circ} \mathrm{E}$ Longitude; (2) the event was recorded by at least six stations with clear $\mathrm{P}$ or $\mathrm{S}$ arrivals; (3) $M_{\mathrm{L}} \geqslant 3.0$ and focal depth is less than $40 \mathrm{~km}$.

In this study, a two-step location technique was employed for earthquake relocation. These two processes can relocate an event's absolute and relative positions more accurately. In the first step, we use the three-dimensional velocity structure location method (3DLOC; Thurber and Eberhart-Phillips, 1999) to improve each event's location precision. The hypoDD equations are built according to Geiger's equation for earthquake location, and the method calculates travel times in a layered velocity model for the current hypocenters at the station where the phase was recorded. The double-difference residuals for pairs of earthquakes at each station are minimized by weighted least squares using the method of singular value decomposition (SVD) or the conjugate gradients method (LSQR) (Waldhauser and Ellsworth, 2000). The SVD method can be useful in examining small populations (about 100 events), whereas the LSQR method is capable of solving for large 
populations of earthquakes efficiently (thousands of events). Therefore, we used the LSQR method to relocate the events. The ray tracing method of Thurber et al. (1993) and the three-dimension P and S velocity structure model determined by Chen and Shin (1998) was also used in the study. Existing tomographic methods of analysis still do not reflect actual velocity structure, and the hypoDD is the best currency available method to relocate earthquakes. For the input data of the hypoDD method, we used the combination of ordinary phase picks from earthquake catalogs. Based on this two-step relocation method, the 3D relocation adjusts the earthquake location in the region, where the lateral structural velocity changes violently in short distance, and the hypoDD method adjusts the relative of locations for the earthquake clusters. For the previous study in eastern Taiwan, the 3D locations were shifted $5.2 \pm 4.1 \mathrm{~km}$ with to the NW, while the hypoDD method adjusted $2.5 \pm 2.0 \mathrm{~km}$ with no significant direction in horizontal (Kuochen et al., 2004).

\subsection{Methods of determining focal mechanisms and rupture planes}

Based on the relocation hypocenters and the first $\mathrm{P}$ polarities focal mechanisms of $M_{\mathrm{L}} \geqslant 3.0$ events were determined. We used the Finite Dimension Source Model method (FDSM) to calculate the synthetic waveforms of two nodal planes from the first motion focal mechanism, calculated the errors $(E)$ between synthetic waveform and recorded waveforms from the Taiwan Strong Motion Instrumentation Program stations (TSMIP). We determined the rupture plane using the procedure of Kao and Jian (2001). The index of waveform misfitting is defined as follows:

$$
\begin{aligned}
& E_{i}=1-\frac{\int_{0}^{T} f_{i}(t) g_{i}(t) \mathrm{d} t}{\sqrt{\int_{0}^{T} f_{i}^{2}(t) \mathrm{d} t} \sqrt{\int_{0}^{T} g_{i}^{2}(t) \mathrm{d} t}} \\
& \text { Misfit }=\frac{1}{i} \sum_{i} E_{i}
\end{aligned}
$$

\section{$E$ : error}

$f$ : the recorded waveform

$g$ : the synthetic waveform

$i$ : the station numbers

Misfit: the index of waveform misfitting (the number is from 0 to 2, 0: complete fitting; 2: no fitting)

\section{Results}

The distribution of the epicenters and hypocenters are oriented perpendicular to the major structures in eastern Taiwan; focal mechanisms are listed in Table 2. After relocation, the main shock epicenter was located at $121.324^{\circ} \mathrm{N}$ and $23.106^{\circ} \mathrm{E}$, with a focal depth of $15.7 \pm 0.27 \mathrm{~km}$. In contrast to the CWB location (Table 1), we suggest that the main shock is located $2 \mathrm{~km}$ eastward and at the focal depth of $15.7 \pm 0.27 \mathrm{~km}$.

According to the relocated hypocenters distribution, the Chengkung earthquake sequences can be classified into three seismic clusters (Fig. 3):

(1) Events located in the east of the Longitudinal Valley define a clear seismic zone that defines an east-dipping fault plane;

(2) Events occurred in the southern end of the Chihshang fault with focal depths ranging from 7 to $8 \mathrm{~km}$;

Table 2

\begin{tabular}{|c|c|c|c|c|c|c|c|c|c|c|c|}
\hline No. & Origin time, $\mathrm{UT}^{\mathrm{a}}$ & Long. ${ }^{a}$ & Lat. $^{\mathrm{a}}$ & Depth $^{\mathrm{a}}$ & $M_{\mathrm{L}}^{\mathrm{a}}$ & Strike $(1)^{b}$ & $\operatorname{Dip}(1)^{b}$ & Rake $(1)^{b}$ & Strike $(2)^{b}$ & $\operatorname{Dip}(2)^{b}$ & Rake $(2)^{b}$ \\
\hline 1 & 2003/12/10/04:33 & 121.303 & 23.112 & 12.5 & 4.0 & 200.0 & 45.0 & 90.0 & 20.0 & 45.0 & 90.0 \\
\hline 2 & $2003 / 12 / 10 / 04: 38$ & 121.324 & 23.106 & 15.7 & 6.6 & 210.0 & 40.0 & 85.0 & 36.5 & 50.2 & 94.2 \\
\hline 3 & $2003 / 12 / 10 / 12: 03$ & 121.273 & 22.948 & 22.5 & 3.5 & 190.0 & 70.0 & 160.0 & 287.1 & 71.3 & 21.2 \\
\hline 4 & $2003 / 12 / 10 / 14: 00$ & 121.280 & 23.153 & 3.9 & 3.7 & 20.0 & 45.0 & 100.0 & 186.0 & 45.9 & 80.1 \\
\hline 5 & $2003 / 12 / 1016: 35$ & 121.292 & 23.074 & 13.6 & 4.5 & 5.0 & 50.0 & 75.0 & 207.6 & 42.3 & 107.1 \\
\hline 6 & 2003/12/10/17:11 & 121.241 & 23.023 & 9.1 & 3.9 & 10.0 & 30.0 & 80.0 & 201.5 & 60.5 & 95.7 \\
\hline 7 & $2003 / 12 / 10 / 17: 36$ & 121.270 & 22.951 & 22.7 & 3.3 & 20.0 & 50.0 & -90.0 & 200.0 & 40.0 & -90.0 \\
\hline 8 & 2003/12/10/18:01 & 121.295 & 23.022 & 16.5 & 3.7 & 25.0 & 40.0 & 110.0 & 179.6 & 52.8 & 74.0 \\
\hline 9 & $2003 / 12 / 10 / 20: 50$ & 121.294 & 23.148 & 9.7 & 3.8 & 5.0 & 20.0 & 80.0 & 195.6 & 70.3 & 93.6 \\
\hline 10 & $2003 / 12 / 10 / 20: 57$ & 121.292 & 23.146 & 8.7 & 3.2 & 20.0 & 50.0 & 80.0 & 215.3 & 41.0 & 101.7 \\
\hline 11 & $2003 / 12 / 10 / 22: 31$ & 121.295 & 23.125 & 9.0 & 3.5 & 140.0 & 75.0 & -140.0 & 37.7 & 51.6 & -19.3 \\
\hline 12 & 2003/12/11/00:01 & 121.403 & 22.802 & 28.3 & 5.7 & 10.0 & 30.0 & 80.0 & 201.5 & 60.5 & 95.7 \\
\hline 13 & 2003/12/11/02:22 & 121.224 & 22.980 & 6.8 & 4.5 & 355.0 & 20.0 & 85.0 & 180.3 & 70.1 & 91.8 \\
\hline 14 & 2003/12/11/09:49 & 121.266 & 22.954 & 21.5 & 3.7 & 185.0 & 40.0 & -25.0 & 294.7 & 74.2 & -127.3 \\
\hline 15 & $2003 / 12 / 11 / 16: 12$ & 121.379 & 22.812 & 26.6 & 4.1 & 5.0 & 20.0 & 80.0 & 195.6 & 70.3 & 93.6 \\
\hline 16 & 2003/12/11/19:04 & 121.288 & 22.944 & 24.7 & 4.5 & 5.0 & 40.0 & 75.0 & 204.3 & 51.6 & 102.3 \\
\hline 17 & $2003 / 12 / 11 / 22: 49$ & 121.197 & 23.048 & 7.5 & 5.1 & 190.0 & 45.0 & 90.0 & 10.0 & 45.0 & 90.0 \\
\hline 18 & $2003 / 12 / 11 / 22: 57$ & 121.194 & 23.054 & 7.2 & 4.7 & 190.0 & 40.0 & 60.0 & 47.0 & 56.2 & 112.8 \\
\hline 19 & 2003/12/16/14:13 & 121.325 & 23.128 & 16.1 & 4.9 & 230.0 & 50.0 & 100.0 & 34.7 & 41.0 & 78.3 \\
\hline 20 & 2003/12/18/05:33 & 121.066 & 22.876 & 10.3 & 4.8 & 210.0 & 45.0 & 70.0 & 57.2 & 48.4 & 108.9 \\
\hline 21 & 2003/12/21/05:16 & 121.078 & 22.879 & 12.1 & 4.1 & 190.0 & 60.0 & 80.0 & 29.4 & 31.5 & 106.7 \\
\hline
\end{tabular}

Source parameters of studied earthquakes

${ }^{\mathrm{a}}$ Origin time (yr/month/day/h:min:s), epcentral locations $\left({ }^{\circ} \mathrm{N},{ }^{\circ} \mathrm{E}\right)$, depth $(\mathrm{km})$ and local magnitudes are after the two step relocation method.

${ }^{\mathrm{b}}$ (1) and (2) are revealed fault plane 1 and fault plane 2 , respectively. 


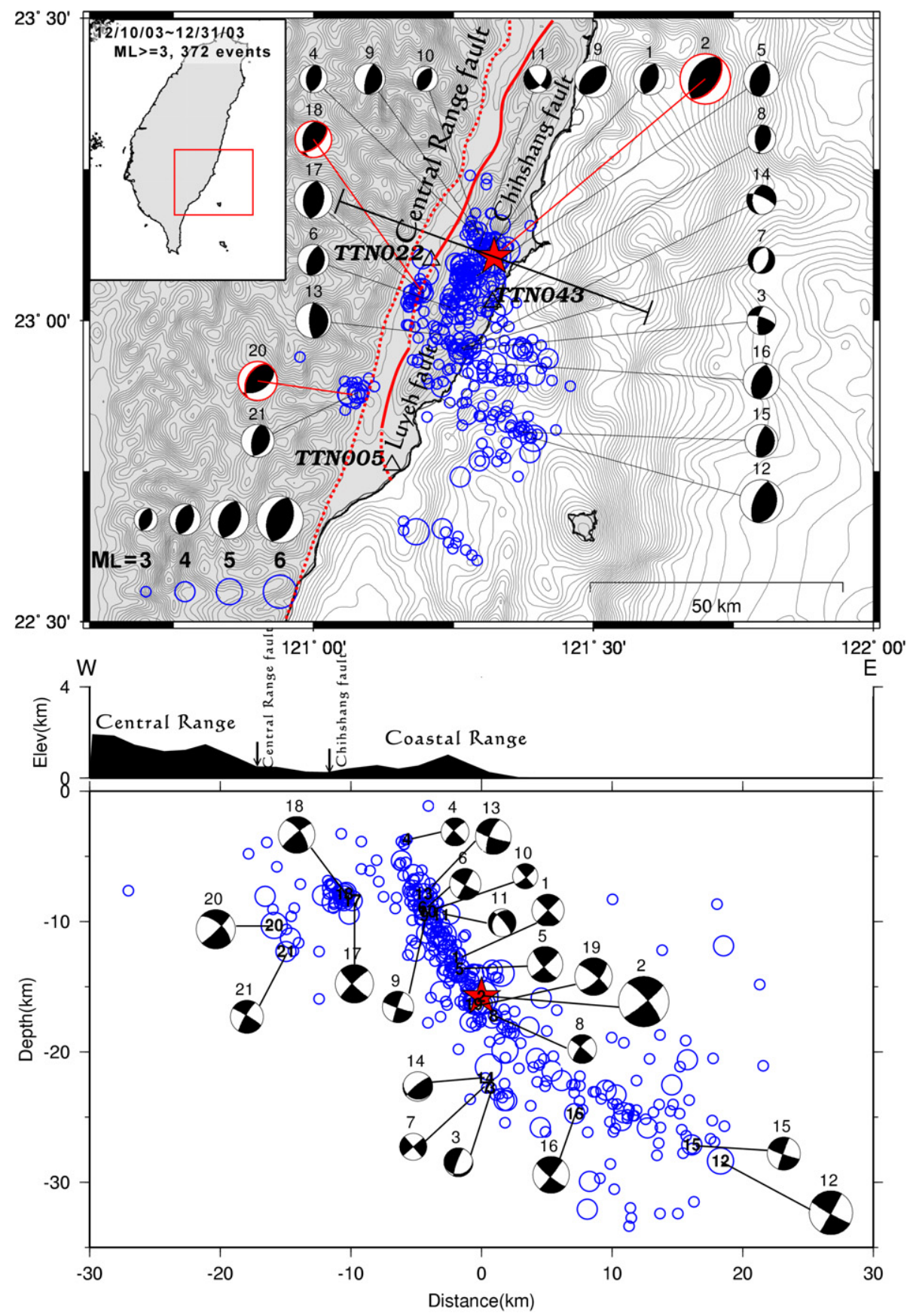

Fig. 3. (upper) The distribution of relocated epicenters of 2003 Chengkung earthquake sequences. Three fault plane solutions represent the optimum fault planes of the three seismic clusters of the Chengkung earthquake sequence (No. 2, 18, and 20). The bold arcs in the beach balls show the rupture planes. Triangles are TSMIP stations. (lower) Cross-section showing the projected hypocenters and $M_{L} \geqslant 3.0$ focal mechanisms.

(3) Events occurred in the western side of the Luyeh fault with focal depths from 5 to $12 \mathrm{~km}$.

Besides thrust events, which most solutions of the focal mechanisms represent, one normal type, two normal with strike-slip component, and one thrust with strike-slip component were also identified (Table 2).

Since the 2003 earthquake sequence is dominated by cluster 1, we interpret events occurring east of the Longitudinal Valley as representing the seismic source of the Chen- gkung earthquake. The other two smaller clusters were perhaps triggered by the Chengkung earthquake.

To identify the rupture planes of the clusters, the FDSM was applied in this study. We selected three larger events (event \#2, \#18, and \#20 in Table 2) for each cluster in order to identify the possible orientation of potential rupture planes (Fig. 3). We used near source strong motion records for the FDSM analysis.

The best fitting FDSM result for event \#2, located in the east of the LV, is the east-dipping nodal plane, (Fig. 5) 


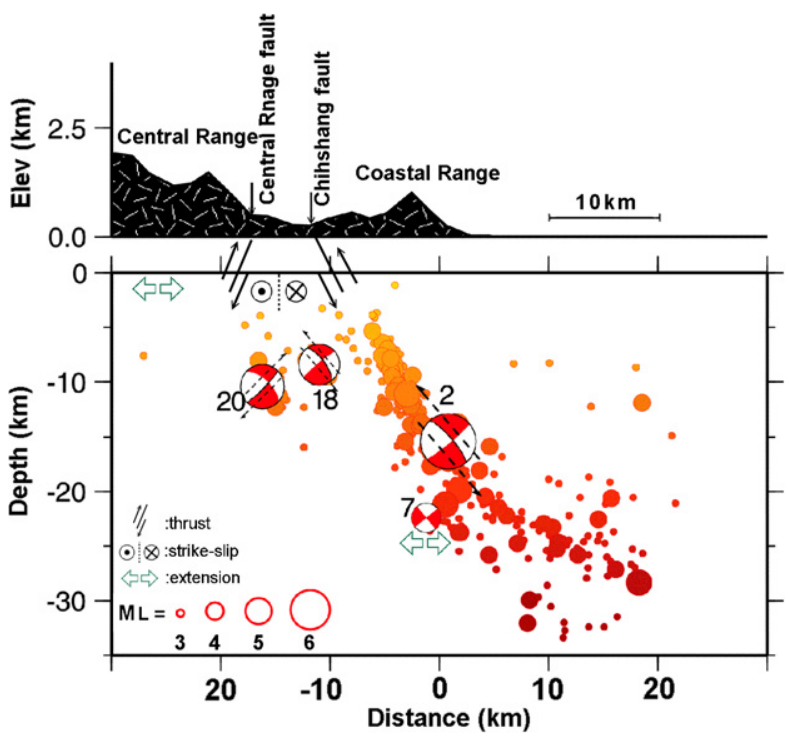

Fig. 4. The three seismic clusters of the Chengkung earthquake sequence and the related tectonic environment in southeastern Taiwan.

which we identify as the rupture plane. Surprisingly, it also coincides well with the background seismic pattern. The best fitting FDSM result of event \#18, located at the southern end of the Chihshang fault, is the east-dipping nodal plane (Fig. 6).

For event \#20, located at the western side of the Luyeh fault, we used a similar method which shows that the westdipping nodal plane (strike, $210^{\circ}$; dip, $45^{\circ}$; slip, $70^{\circ}$ ) fits much better than the east-dipping nodal plane (Fig. 7). The west dip of the fault plane suggests a fault plane different than main fault.

Furthermore, the dip of the rupture plane of the focal mechanisms generally follow the distribution of earthquake, but a few do not. These include focal mechanisms (\#6, \#9, and \#13) shown in shallow depth $(0-10 \mathrm{~km})$ where the rupture plane are between $20^{\circ}$ and $30^{\circ}$.

\section{Discussions}

\subsection{Chengkung seismic zone and the Chihshang fault}

Our data indicate that the main seismic cluster of Chengkung earthquake sequence coincides with the Chengkung seismic zone, the construction of an east-dipping plane imaged by background micro seismicity east of LV at a depth of 0-25 km (Chen and Rau, 2002; Lee et al., 2003; Kuochen et al., 2004; Figs. 1 and 3). The seismic source of 2003 Chengkung earthquake is apparent from this seismic zone. Efforts to further identify the surface fault are important because the 1951 Taitung earthquake included surface rupture and is believed to have come from the same source. Based on the aftershock geometry and focal mechanism solutions, the main seismic cluster of the Chengkung earthquakes occurred on the Chihshang fault. (Hsu, 1962).

According to previous studies (Yu et al., 1994; Angelier et al., 2000), the Chihshang fault is located along the western Coastal Range. Its seismic-related history (1951 Taitung earthquake) and tectonic-influenced geomorphic features indicate that this system is quite active (Cheng et al., 1996; Chung et al., 2003; Shyu et al., 2006). Geodetic results also demonstrate that it is the most active segment of the Coastal Range fault (Yu et al., 1994; Angelier et al., 2000). Fault slip-rate studies by creepmeter measurements show an annual slip velocity of $2.2 \mathrm{~cm} / \mathrm{yr}$ in $\mathrm{N} 40^{\circ} \mathrm{W}$ direction between 1990 and 1997. This velocity is composed of a thrust component with a horizontal shortening of $1.7 \mathrm{~cm} / \mathrm{yr}$ and a left-lateral component of $1.4 \mathrm{~cm} / \mathrm{yr}$ (Angelier et al., 1997, 2000; Lee et al., 1998). GPS and the results generated from repeating triangulation between 1983 and 1988 yield an average velocity of $2.1 \mathrm{~cm} / \mathrm{yr}$ ( $\mathrm{Yu}$ and Liu, 1989; Lee and Angelier, 1993). The high rate of background seismicity of the Chengkung seismic zone can be interpreted as related to the high creep rate along the Chihshang fault. Based on the hypotheses above, the conclusion seems to be that the simple listric shape of the Chengkung
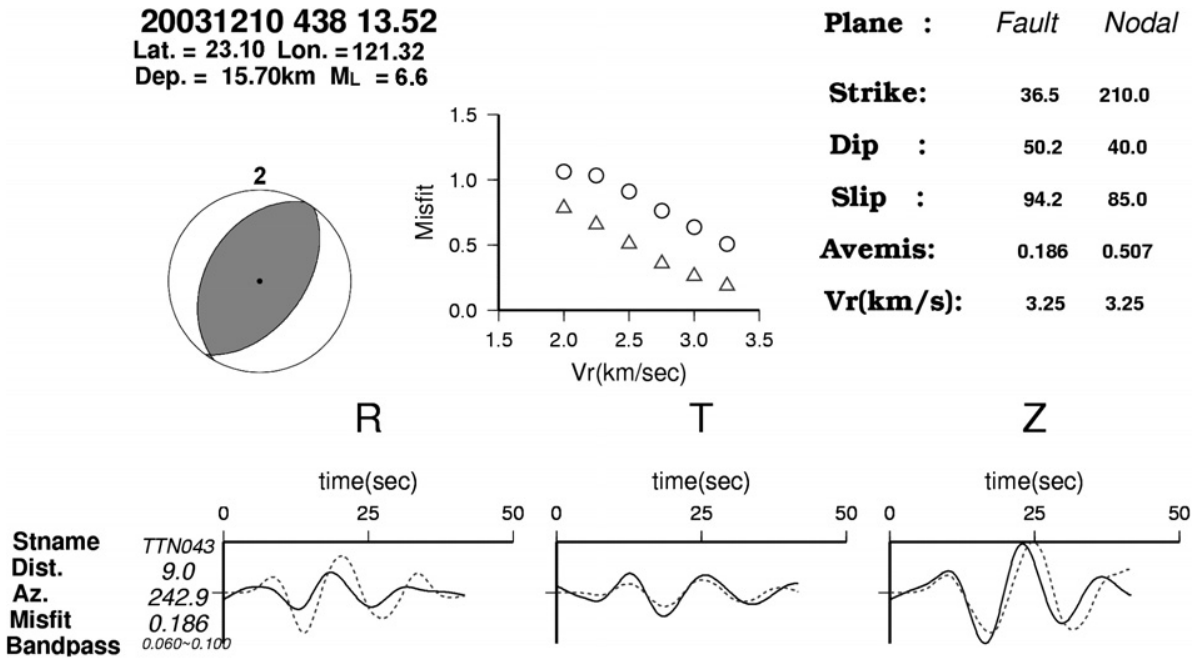

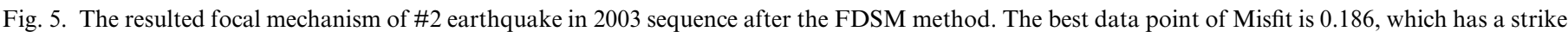
of $36.5^{\circ}$, a dip of $50.2^{\circ}$, and a slip of $94.2^{\circ}$ of the fault plane solution. TSMIP station, TTN043. Vr (km/s), the velocity of the rupture plane. 
20031211225715.41
Lat. $=23.05$ Lon. $=121.19$
Dep. $=7.20 \mathrm{~km} \mathrm{ML}=4.7$
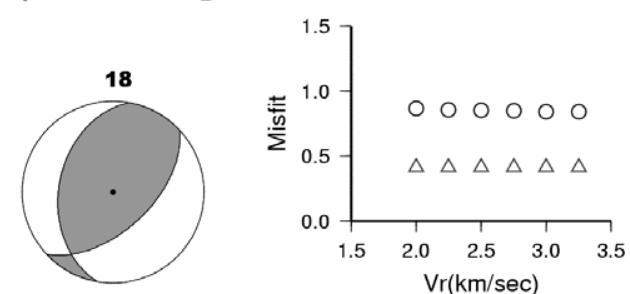

$\mathrm{R}$
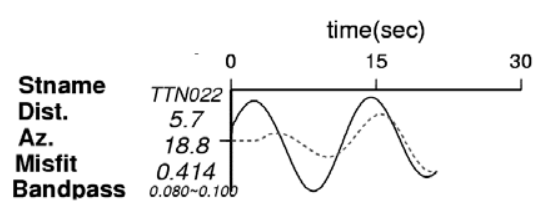

T

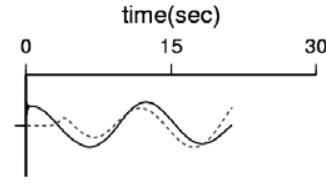

Plane : Fault Nodal

Strike: $\quad 47.0 \quad 190.0$

Dip : $\quad 56.2 \quad 40.0$

Slip : $\quad 112.8 \quad 60.0$

Avemis: $\quad 0.414 \quad 0.840$

$\operatorname{Vr}(\mathbf{k m} / \mathrm{s}): \quad 3.00 \quad 3.25$

Fig. 6. The resulted focal mechanism of \#18 earthquake in 2003 sequence after the FDSM method. The best data point of Misfit is 0.414 , which has a strike of $47.0^{\circ}$, a dip of $56.2^{\circ}$, and a slip of $112.8^{\circ}$ of the fault plane solution. TSMIP station, TTN022.
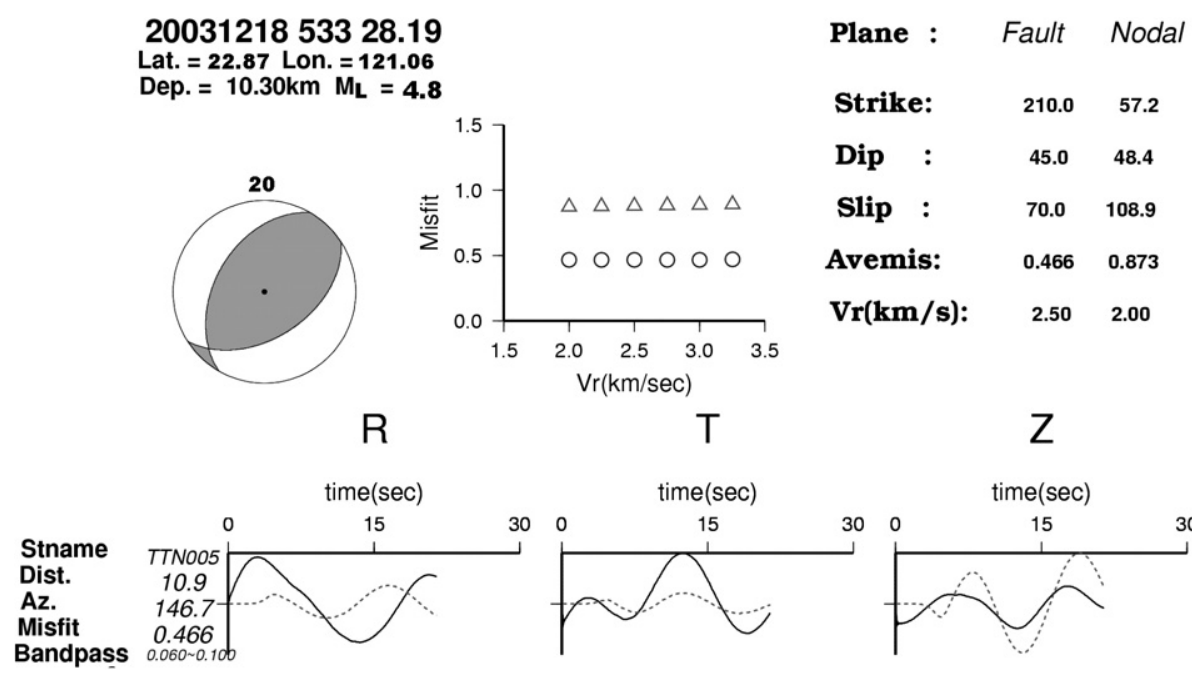

Fig. 7. The resulted focal mechanism of \#20 earthquake in 2003 sequence after the FDSM method. The best data point of Misfit is 0.466 , which has a strike of $210.0^{\circ}$, a dip of $45.0^{\circ}$, and a slip of $70.0^{\circ}$ of the fault plane solution. TSMIP station, TTN005.

seismic zone is the manifestation of the surface Chihshang fault (Figs. 1 and 3). However, the focal mechanisms of 2003 Chengkung earthquake indicate that the thrust solution is inconsistent with the surface displacement defined by geodetic creepmeter studies. In addition, the second aftershock cluster located at the southern end of the Chihshang fault is difficult to relate to the Chihshang fault unless it is a vertical strike-slip fault. These two discrepancies suggest that the Coastal Range fault can not be explained by a simple structural model, although the first order geometry and focal mechanisms are geologically and seismologically compatible.

\subsection{Central range fault system}

Although a large portion of the aftershocks from 2003 Chengkung earthquake occurred in association with the Chengkung seismic zone - the Chihshang fault, some after- shocks in the western side of the Luyeh fault do not occur along the Chihshang fault in the above model. In particular, the FDSM-determined west-dipping rupture plane suggests that this aftershock sequence occurred on another fault. Based on the epicenter locations of the western seismic cluster, it was probably generated by rupture on the Central Range fault and has also been proposed by Biq (1965) and Shyu et al., 2006 (Figs. 3 and 4). The westdipping fault accommodates the shortening across the Central Range. Recent geomorphologic studies suggest that the fault displaces Holocene strata in the central LV (Shyu et al., 2006).

\subsection{Triggered slip}

The seismic source of 2003 Chengkung earthquake not only was the Chihshang fault, but also triggered slip on two minor fault systems (Fig. 3). Given the limited number 
of earthquakes on these two minor fault systems made it hard to understand the relationships between focal mechanisms and background seismicity relative to local fault geometry and the record of large earthquakes. Large earthquake, such as 2003 Chengkung earthquake, offer an opportunity to explore these seismogenic structures. In addition, the fault plane solutions (\#3, \#7, and \#14; Fig. 3) that indicate normal faulting under the major seismic zone might indicate stress readjustment within the footwall after the main shock. This also suggests that some major faults may be triggered by large nearby seismic zones. These smaller faults play a role in stress accommodation and are typically undetectable in earthquake catalogs developed over periods of decades.

\section{Conclusions}

Our data suggest the Chengkung earthquake sequences can be divided into the three seismic clusters (Fig. 4) that include: (1) a main seismic cluster that coincides with the background seismicity, which is an east-dipping plane; (2) a small seismic cluster that occurs beneath the southern end of the Chihshang fault and; (3) a seismic cluster centered on the western side of the Luyeh fault.

Most of the fault plane solutions are consistent with the reverse faulting; however, three earthquakes with normal fault solutions probably indicate stress readjustment within the footwall after the main shock rupture. Two minor seismic clusters are interpreted as triggered by the Chengkung earthquake. Lastly, the seismic cluster of the Luyeh fault showing the west-dipping reverse fault plane supports the existence of the Central Range fault underneath the Central Range.

\section{Acknowledgement}

This research was supported by the Central Weather Bureau and the National Science Council of the Republic of China.

\section{References}

Angelier, J., Chu, H.T., Lee, J.C., 1997. Shear concentration in a collision zone: kinematics of the Chihshang Fault as revealed by outcrop-scale quantification of active faulting, Longitudinal Valley, eastern Taiwan. Tectonophysics 274, 117-143.

Angelier, J., Chu, H.T., Lee, J.C., Hu, J.C., 2000. Active faulting and earthquake hazard: the case study of continuous monitoring of the Chihshang Fault, Taiwan. J. Geodyn. 29, 151-185.

Biq, C., 1965. The east Taiwan rift. Petroleum Geol. Taiwan 4, 93-106.

Chen, H.H., Rau, R.J., 2002. Earthquake Locations and Focal Mechanisms in an Active Arc-Continent Plate Boundary: the Chihshang Fault of Eastern Taiwan, EOS Trans. AGU, 83(47), Fall Meet. Suppl., Abstract T61-1277.

Chen, Y.L., Shin, T.C., 1998. Study on the earthquake location of 3-D velocity structure in Taiwan area. Meteor. Bull. 42, 135-169.

Cheng, S.N., Yeh, Y.T., Yu, M.S., 1996. The 1951 Taitung earthquake in Taiwan. J. Geol. Soc. China 39 (3), 267-285.
Chung, L.H., Chen, Y.G., Lee, J.C., Shyu, J.B.H., Wang, Y., 2003. Surface Rupture Reevaluation of 1951 Earthquake Sequence in the middle Longitudinal Valley and the Neotectonic Implications. 2003 Annual Meeting of the Geological Society of China, Program with Abstracts, p. 157, (in Chinese).

Carena, S., Suppe, J., Kao, H., 2002. Active detachment of Taiwan illuminated by small earthquakes and its control of first-order topography. Geology 30 (10), 935-938.

Ho, C.S., 1986. A synthesis of the geologic evolution of Taiwan. Tectonophysics 125, 1-16.

Hsu, M.T., 2003. Seismological observation and service in Taiwan (up to 1970). In: Lee, W.H.K., Kanamori, H., Jennings, P.C. (Eds.), Handbook of Earthquake and Engineering Seismology. Academic Press.

Hsu, T.L., 1962. Recent faulting in the Longitudinal Valley of eastern Taiwan. Mem. Geol. Soc. China 1, 95-102.

Hu, J.C., Angelier, J., Yu, S.B., 1997. An interpretation of the active deformation of southern Taiwan based on numerical simulation and GPS studies. Tectonophysics 274, 145-170.

Kao, H., Jian, P.R., 2001. Seismogenic patterns in the Taiwan region: insights from source parameter inversion of BATS data. Tectonophysics 333, 179-198.

Kuochen, H., Wu, Y.M., Chang, C.H., Hu, J.C., Chen, W.S., 2004. Relocation of the eastern Taiwan earthquakes and its tectonic implications. TAO 15, 647-666.

Lee, J.C., Angelier, J., 1993. Localisation des deformations actives et traitement des donnèes gèodèsiques: l'exemple de la faille de la Vallèe Longitudinale, Taiwan. Bulletin de la Sociète Géologique de France 164 (4), 533-570.

Lee, J.C., Angelier, J., Chu, H.T., Yu, S.B., Hu, J.C., 1998. Plateboundary strain partitioning along the sinistral collision suture of the Philippine and Eurasian plates: analysis of geodetic data and geological observation in southeastern Taiwan. Tectonics 17 (6), 859-871.

Lee, J.C., Angelier, J., Chu, H.T., Hu, J.C., Jeng, F.S., Rau, R.J., 2003. Active fault creep variations at Chihshang, Taiwan, revealed by creepmeter monitoring, 1998-2001. J. Geophys. Res. 108, B11, 2528, doi:10.10129/2003JB002394.

Legrand, D., Delouis, B., 1999. Determination of the fault plane using a single near-field seismic station with a finite-dimension source model. Geophys. J. Int. 138, 801-808.

Lu, C.Y., Chan, Y.C., Lee, J.C., Chu, H.T., Malavieille, J., 2002. Active continental growth under transpressional tectonics-example from southeastern Taiwan. Western Pacific Earth Sci. 2 (1), 37-46.

Shyu, J.B.H., Chung, L.H., Chen, Y.G., Lee, J.C., Sieh, K., 2006. Reevaluation the surface ruptures of the November 1951 earthquake series in eastern Taiwan, and its neotectonic implications, submitted to J. Asian Earth Sci.

Teng, L.S., 1992. Geotectonic evolution of Tertiary continental margin basins of Taiwan. Petroleum Geol. Taiwan 27, 1-19.

Thurber, C.H., 1993. Local earthquake tomography: velocities and Vp/ Vs- theory. In: Iyer, H.M., Hirahara, K. (Eds), Seismic Tomography: Theory and practice, Chapman \& Hall, London, UK.

Thurber, C.H., Eberhart-Phillips, D., 1999. Local earthquake tomography with flexible gridding. Comp. Geosci. 25, 809-818.

Waldhauser, F., Ellsworth, W.L., 2000. A double-difference earthquake location algorithm: method and application to the northern Hayward fault, California. Bull. Seismol. Soc. Am. 90, 1353-1368.

Yu, M.S., Chu, H.T., Hou, C.H., Lee, J.C., 1994. The Chengkung earthquake of May 29, 1992 and the Chihshang Fault. Bull. Central Geol. Surv. 9, 107-121, (in Chinese).

Yu, S.B., Liu, C.C., 1989. Fault creep on the central segment of the Longitudinal Valley Fault, Eastern Taiwan. Proc. Geol. Soc. China 32 (3), 209-231.

Yu, S.B., Chen, H.Y., Kuo, L.C., 1997. Velocity field of GPS stations in the Taiwan area. Tectonophysics 274, 41-59. 